\title{
Navigating state and society: new naval histories of the long eighteenth-century
}

Evan Wilson, A Social History of British Naval Officers, 1775-1815 (Woodbridge: Boydell

Press, 2016)

Ellen Gill, Naval Families, War and Duty in Britain, 1740-1820 (Woodbridge: Boydell Press, 2016)

Thomas Malcomson, Order and Disorder in the British Navy 1793-1815: Control, Resistance, Flogging and Hanging (Woodbridge: Boydell Press, 2016)

Robert Sutcliffe, British Expeditionary Warfare and the Defeat of Napoleon, 1793-1815 (Woodbridge: Boydell Press, 2016)

In the last few years, a heated debate has sprung up around naval impressment. The shadow of the press gang has long loomed over the eighteenth century Royal Navy, but it is only in the last decade that devoted studies on this controversial practice have emerged. Scholars come from a range of historical backgrounds, each of them bringing different methodologies and historical outlooks. Jeremiah Dancy's quantitative study of naval impressment in the late eighteenth century has argued that the number of sailors who suffered at the hands of the press gang was far lower than previous calculations allowed, suggesting instead that volunteers made up the majority of seamen in the Royal Navy. ${ }^{1}$ To say that his findings have been controversial would be something of an understatement. Isaac Land has critiqued Dancy's work, accusing him of neglecting published discourse and relying too heavily on state archives. ${ }^{2}$ Christopher Magra has opposed any attempt to downplay the importance of the practice, arguing that anger over British impressment was at the heart of American discontent in the lead-up to the American War of Independence. ${ }^{3}$ Most recently, Nicholas Rogers' study of British newspapers argues that impressment was a contentious issue

\footnotetext{
${ }^{1}$ J. Ross Dancy, The Myth of the Press Gang: Volunteers, Impressment and the Naval Manpower Problem in the Late Eighteenth Century (Woodbridge: Boydell Press, 2015)

${ }^{2}$ Isaac Land, 'New Scholarship on the Press Gang', parts 1 and 2. See http://porttowns.port.ac.uk/press-gang-1/ and http://porttowns.port.ac.uk/press-gang2/

${ }^{3}$ Christopher P. Magra, Poseidon's Curse: Naval Impressment and Atlantic Origins of the American Revolution (Cambridge: Cambridge University Press, 2016).
} 
throughout the late eighteenth century. ${ }^{4}$ Each has approached the subject from a different very different methodological perspective, consulted a different set of sources, and unsurprisingly come out with very different conclusions.

The debate demonstrates that the study of navies - be it their personnel, their socio-cultural impact, or our understanding of the land-based institutions that sustained them - remain an engaging subject matter for historians. Most notable is the variety of scholars who have turned to this 'traditional' naval subject. Few of the historians mentioned would describe themselves as a naval historian. Dancy comes closest to that description, though his work asks wider questions about how the state mobilised manpower and resources. Isaac Land, a historian of political culture and a pioneer of 'coastal history' has little interest in 'naval historians asking naval questions of naval archives'. ${ }^{5}$ Magra is a historian of Revolutionary America, while Nicholas Rogers is one of Britain's leading social historians. All have identified the navy as fertile ground for analysis, and as a result, have opened new perspectives on the subject.

These works are representative of what we might call a 'new naval history' that looks beyond issues of leadership, tactics and technology to consider how the navy fits into wider historiographies and methodologies. In the past, naval history has suffered from an academic trend that has ostracised military studies from the historical mainstream. As a field, its reputation remains traditional, technical, introspective and triumphalist. ${ }^{6}$ And yet, a close inspection of recent work offers a very different picture, with new scholarship on this history of the navy moving the field far from its original disciplinary moorings. Historians have examined the navy as a social and cultural force - a lens on gender, class and national identity. Other studies have considered the links between the navy, the state, and its relationship with imperialism, while the growth of global and oceanic history has furnished works on encounter and cultural exchange. ${ }^{7}$ The transformation of naval history owes

\footnotetext{
${ }^{4}$ Nicholas Rogers, 'British impressment and its discontents', The International Journal of Maritime History, Vol. 30, No. 1 (2018), pp. 52-73. This follows his earlier work: Nicholas Rogers, The Press Gang: Naval Impressment and its opponents in Georgian Britain (London: Continuum, 2007)

${ }^{5}$ Land, 'New Scholarship on the Press Gang', part 2 http://porttowns.port.ac.uk/press-gang2/

${ }^{6}$ Alan James, 'Raising the profile of naval history: an international perspective on early modern navies'. The Mariner's Mirror, 97:1 (February 2011), 195-6; Andrew Lambert, 'The Construction of Naval History $1815-$ 1914', The Mariner's Mirror, 97:1 (February 2011), p. 217; Richard Harding, Modern Naval History: Debates and Prospects (London: Bloomsbury, 2016), p. 6

${ }^{7}$ It is impossible to list all the relevant scholarship here, but some key works include: Robert Blyth, Andrew Lambert and Jan Ruger (eds), The Dreadnought and the Edwardian Age (Farnham: Ashgate, 2011); Quintin
} 
something to the renaissance in the broader discipline of maritime history, as already noted by Glen O’Hara, Karen Widen and David Cannadine. ${ }^{8}$ Within this, though, studies focusing on the Royal Navy have excited particular attention, with scholars tempted by the promise of an extensive source base and burgeoning scholarly interest.

The 'new naval history' has chronological concentrations. Scholarship on the nineteenthcentury navy, for example, has frequently explored ideas of nation and identity. ${ }^{9}$ Recent work on the eighteenth century has focused more on the relationship between the navy and British society, and secondly, the relationship between the navy and the British state. The four new works in this review offer four distinct takes on this 'new naval history'. Each uses the eighteenth-century Royal Navy as a case study for wider historiographies. Social histories have long been a crucial part of naval history's bibliography, beginning with Michael Lewis' A Social History of the Navy, first published in 1960, and N.A.M. Rodger's seminal The Wooden World. ${ }^{10}$ A number of recent works seek to question some of their main assumptions through more focused studies. ${ }^{11}$ Evan Wilson's book on the social history of naval officers, Ellen Gill's study of naval families, and Malcomson's study of shipboard 'disorder' continue this work. In a similar vein, the relationship between the navy and the state has received

Colville, 'Corporate Domesticity and Idealised Masculinity: Royal Naval Officers and their Shipboard Homes, 1918-39’, Gender and History, 21, no. 3 (2009), pp. 499-519; Mary Conley, From Jack Tar to Union Jack: Representing Naval Manhood in the British Empire, 1870-1918 (Manchester: Manchester University Press, 2009); Timothy Jenks, Naval Engagements: Patriotism, Cultural Politics, and the Royal Navy, 1793-1815 (Oxford: Oxford University Press, 2006); Isaac Land, War, Nationalism, and the British Sailor, 1750-1850 (London: Palgrave Macmillan, 2009); Don Leggett, Shaping the Royal Navy: Technology, Authority and Naval Architecture, c. 1830-1906 (Manchester: Manchester University Press, 2015); Margarette Lincoln, Representing the Royal Navy: British Sea Power, 1750-1815 (London: Ashgate, 2002); Joshua Newton, 'Slavery, Sea Power and the State : The Royal Navy and the British West African Settlements, 1748-1756', Journal of Imperial and Commonwealth History, 41:2 (2013) pp. 171-193; Christer Petley and John McAleer, The Royal Navy and the British Atlantic World, c. 1750-1820 (London: Palgrave Macmillan, 2016); Duncan Redford (ed.), Maritime History and Identity: The Sea and Culture in the Modern World (London: I.B. Tauris, 2014); Laura Rowe, Morale and Discipline in the Royal Navy during the First World War (Cambridge: Cambridge University Press, 2018); Jan Ruger, The Great Naval Game: Britain and Germany In the Age of Empire (Cambridge: Cambridge University Press, 2009); Daniel Owen Spence, Colonial naval culture and British imperialism 1922-67 (Manchester: Manchester University Press, 2015)

${ }^{8}$ Karen Wigen, 'Oceans of History', American Historical Review, cxi (2006); Glen O'Hara, “"The Sea is Swinging into View': Modern British Maritime History in a Globalised World', English Historical Review, CXXIV No. 510, pp. 1109-1134; David Cannadine (ed.), Empire, the Sea and Global History: Britain's Maritime World, c. 1763-c. 1840 (Basingstoke: Palgrave Macmillan, 2007).

${ }^{9}$ For a similarly conceived review of nineteenth-century naval history see Don Leggett, 'Navy, nation and identity in the long nineteenth century', Journal for Maritime Research, Vol. 13, No. 2, (November 2011), pp. 151-163.

${ }^{10}$ Michael Lewis, A Social History of the Navy, 1793-1815, London: Allen \& Unwin, 1960; N. A. M. Rodger, The Wooden World: an Anatomy of the Georgian Navy (London: Collins, 1986)

${ }^{11}$ See for example Margarette Lincoln, Naval Wives and Mistresses (London: National Maritime Museum, 2007) and Cavell, S. A., Midshipmen and Quarterdeck Boys in the British Navy, 1771-1831 (Woodbridge: Boydell and Brewer, 2012) 
increasing attention, with scholars building on John Brewer's 'fiscal-military state' to consider how resources, economics and government have shaped naval power. More recently, these have evolved into wider questions about the existence of a 'fiscal-naval state' or indeed a 'contractor state'. Robert Sutcliffe's new monograph on British expeditionary warfare follows firmly in these footsteps. ${ }^{12}$

This is therefore an article about 'new' naval history, but in particular, how it can include and inform wider debates; in this sense, naval history is truly navigating both state and society. One final commonality is that they have all been produced by the same publishing house, Boydell and Brewer. In the last decade, Boydell have developed an extensive list of titles that focus on the maritime world (including, it ought to be pointed out, this author's first monograph) and thus finds itself as an important mediator in the continued success of "new naval history'. In consequence, this review of four new books is also an assessment of an important new historiographical trend, as well as a nascent academic series.

Evan Wilson's book A Social History of British Naval Officers offers an innovative take on the British naval officer corps of the late eighteenth century. At its heart are two questions: were naval officers gentlemen, and what can that tell us about British society? Right from the outset, then, Wilson is using the navy to illuminate wider historical debates, and ultimately delivers on this ambitious agenda. Unlike previous studies of the navy's officer corps, such as that of Michael Lewis, Wilson's study is not restricted to high-ranking personnel, but instead represents a wide-ranging sample of nearly a thousand commissioned and warrant officers, that includes the oft-forgotten lieutenants and warrant officers. Nor is this simply a quantitative study, but one which utilises diaries, letters and memoirs to add texture to his wider findings. Chief among these is the discovery of the 'middling origins of British naval

\footnotetext{
${ }^{12}$ For the "fiscal-military state see N.A.M. Rodger, 'From "Military Revolution" to "fiscal-naval state", Journal for Maritime Research, Vol. 13, No. 2 (November 2011), pp. 119-128. For the 'contractor state' see Roger Knight and Martin Wilcox, Sustaining the Fleet, 1793-1815: War, the British Navy and the contractor state (Woodbridge, 2010); H.V. Bowen and A Gonzales Enciso (eds), Mobilising Resources for War: Britain and Spain at work during the early modern period (Pamplona, 2006); R. Torres Sanchez (ed), War, State and Development: Fiscal-military states in the eighteenth century (Navarra, 2007). See also Gareth Cole, Arming the Royal Navy, 1793-1815: The Office of Ordnance and the State (London: Pickering and Chatto, 2012) and James Davey, The Transformation of British Naval Strategy: Seapower and Supply in Northern Europe, 1808-1812 (Woodbridge: Boydell and Brewer, 2012).
} 
officers'. ${ }^{13}$ Wilson finds that the sons of aristocrats made up a mere 4 per cent of naval officers, while the son of a lord was no more likely to reach post-rank than the son of a merchant. There were, he argues, two distinct groups of naval officers, but this was not a division based on social class. Instead it was based on merit and ability, with an 'elite' (roughly 20 per cent) who were able to reach the rank of post-captains and admirals, and a vast majority who failed to do so. Both, argues Wilson, struggled to meet the contemporary requirements of gentility, but both played a role in changing what it meant to be a gentleman in eighteenth-century Britain. ${ }^{14}$

Wilson's database offers a number of revealing findings, some of which confirm what we already knew. We learn that most officers were from London, Kent, Hampshire and the southwest, as previous studies have also found, and that 72 per cent of the officer corps was English. Forty per cent of officers joined the navy between ages of 12 and 15 . The navy contained far more officers than could be employed at sea, with at least two qualified lieutenants for every position: 7 per cent of men who passed the lieutenants exam never received a commission. ${ }^{15}$ Other conclusions begin to re-shape our understanding of the Royal Navy's officers. An analysis of lieutenants' passing certificates reveals the remarkably high standards of technical training required by the navy, not least the fact that candidates were required to demonstrate the competence of an able seaman to pass. The chapter on warrant officers' careers is especially revealing. This group came from very similar backgrounds to their commissioned 'superiors', fundamentally altering the way we think about shipboard social hierarchies. They also posed the greatest problem for the Admiralty, for while there was a constant oversupply of young ambitious lieutenants, warrant officers such as surgeons and masters could more easily take their labour into the civilian world. Here we see the mitigated reach of the eighteenth-century state, for while the Admiralty encouraged many lieutenants to become masters, few of them did so. ${ }^{16}$

The book outlines various social worlds, with chapters dealing with the education of young gentlemen, commissioned officers' careers, and then warrant officers' careers. Most revealing, though, are the chapters towards the end of the book, that seek to look beyond the

\footnotetext{
${ }^{13}$ Evan Wilson, A Social History of British Naval Officers, 1775-1815 (Woodbridge: Boydell Press, 2016), p. 87

${ }^{14}$ Wilson, British Naval Officers, p. 7

${ }^{15}$ Wilson, British Naval Officers, pp. 14-17

${ }^{16}$ Wilson, British Naval Officers, p. 82
} 
wardroom. In a wide-ranging chapter on 'International and Domestic Comparisons', Wilson places British naval officers into the broader context of British and European society. He demonstrates clearly that unlike their peers on land, naval officers spent their adolescence learning the technical skills of their profession rather than gaining the classical education expected of a gentleman. These fundamental technical skills, required of all commissioned officers, had no parallel in army regiments which continued to rely on the purchase system to structure promotion and appointments. Wilson suggests that the navy might have had more in common with like Royal Artillery and Engineers, whose training and promotion more easily mirrored that of the navy, but in reality, 'British naval officers had more in common with Portuguese, Danish or Genoese sailors than they did with British civilians'. ${ }^{17}$

And yet, for all that naval officers were in some ways exceptional, they remained firmly wedded to wider social norms and practices. The most imaginative chapter in the book is that which considers 'Naval Officers' Social Status', in which Wilson argues convincingly that the navy defined gentility not by birth but by behaviour. It mattered far more that an officer behaved like a gentleman, rather than inheriting gentility from a large estate or an aristocratic title. As the author puts it, "the most successful officers were those that impressed their superiors, not those that had impressive fathers'. ${ }^{18}$ In this, Wilson sees the navy aligning with a broader social trend, whereby gentility of birth was eclipsed by gentility of behaviour. Paul Langford has noted that the rank of gentlemen was slowly eroded as middling families with little or no land began to claim it for their own, while Linda Colley has noted that the intense fears of revolution and invasion during the 1790s and 1800s reinforced the necessity of incorporating martial values into Britain's riling classes and into British masculinity. ${ }^{19}$ In this, Wilson is right to say that the navy's importance for national survival meant that it could test the boundaries of social acceptability during this period like no other. Indeed, Wilson goes one step further, and tentatively suggests that by claiming to be gentlemen, naval officers expanded the boundaries of genteel behaviour. In this, we see the Royal Navy shaping, rather than simply reflecting, social change.

\footnotetext{
${ }^{17}$ Wilson, British Naval Officers, p.p. 174-5

${ }^{18}$ Wilson, British Naval Officers, p. 122

${ }^{19}$ Paul Langford, A Polite and Commercial People: England 1727-1783 (Oxford: Oxford University Press), pp. 65-6; Linda Colley, Britons: Forging the Nation 1797-1837 (New Haven and London: Yale University Press, 1992), pp. 177-192.
} 
Further work needs to be done on the reception of the officer in British popular culture before this claim can be fully tested, and this book makes clear the need for a fuller study of how naval officers were represented in British society, whether in oils, in print, or in literature. Wilson's final chapter includes a few examples of this media, and it is a pity these are not analysed in more depth. Similarly, I would have liked to have seen a fuller discussion of the individual ambitions of naval officers. These are briefly touched on in the introduction and the sections on prize money and social status go some way to answering this question. However, discussions of celebrity, or of martial identity, are largely absent. What competing emotions charged these young men with the urge to forge a naval career? Was it wealth, riches, status or fame? Again, it may be that a fuller study is required to consider this question, and these remain small criticisms of what is otherwise a very impressive book, and an excellent example of the 'new naval history'. Clearly written, and containing moments of dry wit, this book will become the authority on naval officers at the end of the eighteenth century.

One of the issues that confronted Wilson was the problem of establishing the myriad of alternative ways that social status was transmitted, for example by women or an officer's extended family. ${ }^{20}$ This issue is at the heart of Ellen Gill's study, Naval Families, War and Duty in Britain, 1740-1820, which explores the other side of the coin. Whereas Wilson's book concentrated on the individuals serving in the navy, their backgrounds, status, and careers, Gill focuses instead on the familial connections that linked sailors to communities on shore. Her study explores the competing demands family, war, duty and separation placed on lives of eighteenth-century naval officers, and in the process offers a rich and detailed picture of the familial networks on which officers' relied, and which were absent from Wilson's study. If their focus is different, so are their methodologies. While Wilson's study was founded upon an extensive database, Gill's book ignores such quantitative techniques in favour of a deep and rigorous consultation of written correspondence between naval officers and their families. These differences aside, the two books dovetail serendipitously. For, just as Wilson is able to reveal a complex picture of the naval officers corps, Gill is able to show the more intimate and emotional side of these men. The two should be read (as well as reviewed) in tandem.

\footnotetext{
${ }^{20}$ Wilson, British Naval Officers, p. 84
} 
Central to Gill's thesis is that naval men did not see military service as their only important role; they were also affectionate husbands and sensitive fathers. Men, as well as women, took their domestic role very seriously, even during periods of absence, and used correspondence to provide moral and practical guidance. Despite frequent and sometimes lengthy separations from loved ones, written correspondence allowed naval men to nurture relationships and remain involved in domestic life. Matthew Flinders, for instance, asked his wife to 'write to me constantly, write me pages and volumes', and numerous other spouses followed suit. ${ }^{21}$

As with Wilson, Gill contextualises her study, in this case, using similar writing practices in eighteenth-century British society. Naval men and their wives were not alone in writing voluminous amounts of letters; it was a central part of eighteenth-century life, with letterwriting manuals and epistolary novels offering further evidence of its importance. Gill also demonstrates an excellent grasp of the historiography on the place of family in eighteenthcentury life, which argues that fathers had a crucial moral and domestic role within the home, and that during periods of absence these roles were maintained and indeed reinforced by correspondence. This work also aligns nicely with Margarette Lincoln's work on naval wives and mistresses; while Lincoln focused on the women actors, Gill considers wives and husbands as part of a couple. ${ }^{22}$

If Gill's historiographical reach is excellent, her source base is narrower. The author is alive to the methodological problems of relying on personal correspondence, noting that not every aspect of personal life is represented in family correspondence; subjects such as marital breakdown, adultery and financial mismanagement are rarely mentioned. Letters do not necessarily offer an accurate representation of the writer or their situation, but a carefully constructed image, and Gill is often forced to take the author at their own words. To these problems we might also add: what can we say about those couples that didn't write? There is no doubt that the correspondence examined offers a rosier picture of naval relationships than we might get from other sources. The author acknowledges that Joanne Bailey's work on parish records offer a very different idea of eighteenth-century marriage, and it is not really clear why she did not look at parish records herself, particularly in naval boroughs, which

\footnotetext{
${ }^{21}$ Ellen Gill, Naval Families, War and Duty in Britain, 1740-1820 (Woodbridge: Boydell Press, 2016), p. 25

${ }^{22}$ Margarette Lincoln, Naval Wives and Mistresses (London: National Maritime Museum, 2007)
} 
might have offered a rather different perspective on naval marriage. ${ }^{23}$ She is right to caution us not to be 'overly cynical', and overall her study makes it clear that there was frequently genuine sentiment, emotion and feeling between naval officers and their wives. But it is worth remembering the idealistic nature of this correspondence, and we must keep this in mind when we read of an officer professing their dutiful sentiments towards his wife and family or describing his patriotic yearnings in overly grandiose prose. ${ }^{24}$

It is certainly true to say, as Gill does, that personal correspondence provides an 'extremely valuable window onto the personal lives and experiences of eighteenth-century couples' ${ }^{25}$ Chapters on the 'children of the service' and naval patronage demonstrates how networks of patronage, friendship and support were central to the lives and experiences of naval officers, and skilfully detail instances when social connections paid dividends. She also notes moments when a lack of patronage created insurmountable challenges for men desperate to improve their station; clearly, there was a limit to the meritocracy outlined by Evan Wilson. We are left in no doubt about the importance of patronage as an all-encompassing aspect of eighteenth-century life; something that has also been outlined in a recent thesis by Catherine Beck. ${ }^{26}$ Even more impressive is the chapter 'women of war', which considers female experiences of warfare. For the majority of naval women, loyalty to country was expressed through familial duty, and as Gill notes, 'their patriotism came in the form of resignation in the face of personal hardship'. ${ }^{27}$ Gill is also interested in the contrast between cultural representation and social reality. The image of the uncomplaining wife reconciling her husband's absence with national need was a common theme of naval prints and ballads of the period, and it is fascinating to read letters expressing these same emotions. She also shows how female friendship and companionship was vital not just to the sustenance of naval networks but also emotional well-being.

Perhaps the most original aspect of the book is that Gill considers naval relationships up and down the social spectrum. Chapter 6, 'Prest to Volunteer', considers letters written by the sailor James Whitworth, who saw the navy as 'a hellish prison that was keeping him from his

\footnotetext{
${ }^{23}$ Joanne Bailey, Unquiet Lives: Marriage and Marriage Breakdown in England, 1660-1800 (Cambridge: Cambridge University Press, 2003).

${ }^{24}$ Gill, Naval Families, pp. 32, 35

${ }^{25}$ Gill, Naval Families, p. 16

${ }^{26}$ Catherine Beck, 'Patronage and the Royal Navy 1775-1815' (Unpublished PhD Thesis, University of London, 2017)

${ }^{27}$ Gill, Naval Families, pp. 146-7
} 
home and family'. ${ }^{28}$ Whitworth was certainly not a happy individual when at sea, and one wonders how typical his remarks on the service are; it is a shame that no other sailors' letters are considered, and indeed that this is the shortest of the chapters. Nonetheless, Gill has conducted some impressive sleuthing here, delving down into the log of his ship and found that he had been disciplined and punished, something not mentioned in his letters home; again, we are reminded of the silences contained in correspondence. Similarly impressive is a chapter that looked at over 1,000 petitions written by dockyard workers, offering carefully worded descriptions of their past duty, current suffering and desired compensation. The use of these sources adds a new dimension to the book and allows Gill to analyse in detail the language used by men and women ignored by contemporaries and historians alike. Her analysis of these petitions demonstrates clearly that ordinary people believed a narrative of familial - and particularly female - dependence was valued by their social superiors. ${ }^{29}$

What comes through most clearly from this book is that British society evolved ways to deal with the personal trauma of war and conflict, and that this was felt keenly in the domestic and family setting. Gill's book demonstrates that family, war and duty dominated the lives of naval and military families, and that social and political networks such as family and friendship - often functioning outside of official patronage - offered a means of navigating these treacherous waters. Some of these conclusions are perhaps not surprising, but nonetheless show us how the Royal Navy can be used to reveal wider truths about British society. While the reliance on letters means we are sometimes seeing correspondents as they wanted to be seen, as frequent are the moments when we gain a real insight into the thoughts and feelings of both men and women. Indeed, it is hard not to be moved by the passages that describe Susanna Middleton and Sarah Sturgeon's loss of a child, or of a naval wife commenting sadly on the distance between her husband and his son: 'you my love are such a stranger to him, he does not know what to say to you'. ${ }^{30}$ It reminds us that naval men were not always the unfeeling, patriotic and dutiful men of naval biography portrayed in oil paintings, but instead were individuals frequently confronted with hardship and heartbreak. Furthermore, even while they were away from their families for months and sometimes longer, they remained actively participant in the communities they left behind.

\footnotetext{
${ }^{28}$ Gill, Naval Families, p. 183

${ }^{29}$ Gill, Naval Families, p. 221

${ }^{30}$ Gill, Naval Families, pp. 84, 152, 159.
} 
Thomas Malcomson's book offers a very different perspective on the navy's social world. His Order and Disorder in the British Navy 1793-1815: Control, Resistance, Flogging and Hanging focuses on crews serving on naval ships, viewed through the prism of 'order' and 'disorder'. The Admiralty, he argues, attempted to create order in its fleets through a variety of means, attempts that met with mixed success. For while naval bureaucracies attempted to 'control', they found that sailors - and sometimes officers - had reasons to push against this official oversight. To do this, he uses a very broad definition of 'disorder' and uses inverted commas around this word throughout the book. Alongside more formal and obvious examples of 'disorder', such as desertion and mutiny, he finds smaller, more subtle instances of resistance against the established order. This study therefore goes beyond the work conducted by Eder and Byrn on crime and punishment in the navy, to consider the agency of naval personnel and their relationship with the state. ${ }^{31}$ It is about how order was created, how it was undermined and frustrated, and lastly, about the state's response to this 'disorder'. Conceptually the most intriguing of the books under review here, the author aims to 'expose cracks in the image of a well-run Royal Navy at the end of the Napoleonic Wars'. ${ }^{32}$

In truth, the book offers a much narrower case study than that suggested by its title. Rather than a broad survey of order and disorder in the Royal Navy, it instead offers a precise and quite narrow quantitative sample of ships logs, court martial transcripts and a range of other archival material relating to naval fleets serving on the North American and West Indies stations between 1812 and 1815. The author states that the period 1812-15 'provides an excellent opportunity in which to study the creation of order and the response', but this is never fully explained or justified. ${ }^{33}$ It aligns nicely with Byrn's study of the Leeward Island station which ends in 1812, and throughout the book Malcomson offers some telling comparison between the two case studies, but it does mean his conclusions are limited. It allows no opportunity to consider these notions over different periods of time - other than with comparisons to Byrn and Eder's work - and similarly it offers no sense of whether the findings off North America and the Caribbean would be replicated in other stations. One obvious question, for instance, is whether the Admiralty's ability to 'control' its fleet decreased with distance from London, but this cannot be answered given the case study

\footnotetext{
${ }^{31}$ See for example Markus Eder, Crime and Punishment in the Royal Navy of the Seven Years' War 1755-1763 (Aldershot: Ashgate, 2004) and John D. Byrn, Crime and Punishment in the Royal Navy: Discipline on the Leeward Islands Station 1784-1812 (Aldershot: Scholar Press, 1989).

32 Thomas Malcomson, Order and Disorder in the British Navy 1793-1815: Control, Resistance, Flogging and Hanging (Woodbridge: Boydell Press, 2016), p. 224

${ }^{33}$ Malcomson, Order and Disorder, p. 2
} 
chosen. The case study does allow Malcomson to consider a range of different themes across the station; it is probably best to think of this book as a microcosm of naval social history, offering insights into patronage, prize money, discipline, punishment, all through the prism of 'order' and 'disorder'.

The first section of the book demonstrates how the Admiralty was able to exert a remarkable degree of control over its fleets in North America. 'All officers', writes Malcomson, 'worked within a thick web of written regulations, instructions and orders' ${ }^{34}$ The Regulations and Instructions Relating to His Majesty's Service at Sea, as well as the Articles of War, offered explicit instructions to officer and sailors alike, and held considerable sway. The Regulations and Instructions seems to have had more authority, for the author's research suggests that while the Articles of War were supposed to be read to crews on a weekly basis, this did not occur as frequently as some in London might have liked: 23 of the 50 officers included in this study did not once read the Articles of War. ${ }^{35}$ The Admiralty also used instructions and order books to reinforce its control over ships' crews and had significant control over appointments. Malcomson believes that the expansion of the navy across the eighteenth century prompted the Admiralty to 'increase scrutiny and tighten control over every aspect of its domain', and this argument is certainly borne out. ${ }^{36}$ A good example is John Barrow of the Admiralty writing to Admiral Warren in October 1812 concerning excessive flogging of sailors on the station, noting that the sloop Reindeer inflicted more punishments than befitted a vessel of its class. ${ }^{37}$ This was a remarkable degree of oversight, and further evidence of centralizing tendencies of the state in the early nineteenth century.

The second section of the book deals with 'disorder', beginning with Foucault's statement that 'Where there is power, there is resistance'. ${ }^{38}$ Resistance came in many forms, for example desertion, but also through a range of more subtle ways. In the context of a war with the United States, seamen were able to use American citizenship (whether real or not) to excuse themselves from fighting on the station. There is also a fascinating section on 'everyday forms of resistance', such as disobedience, insolence and disrespect towards officers, though very rarely did this go as far as 'mutinous activity'. Officers and sailors alike

\footnotetext{
${ }^{34}$ Malcomson, Order and Disorder, p. 39

${ }^{35}$ Malcomson, Order and Disorder, p. 24

${ }^{36}$ Malcomson, Order and Disorder, p. 6

${ }^{37}$ Malcomson, Order and Disorder, p. 199

${ }^{38}$ Malcomson, Order and Disorder, p. 107
} 
could also disrupt shipboard harmony through theft and profiteering. Here Malcomson details the smaller examples of everyday theft of belongings on board ship but also on wider, more organised criminal activity on the part of officers. Particularly notable is the case of Vice Admiral Charles Stirling, who was found guilty of profiteering, placed on half pay and made ineligible for promotion. ${ }^{39}$ There are places where we might have hope to see more detail or interpretative insight. There is some fascinating statistical analysis of who deserted, how, and when, but no real attempt to explain the precise motivations of the sailors involved. Malcomson states that non-British sailors were more likely to desert, as were seamen who had served prior to joining the ship, but he doesn't go beyond this. We are left with the proposition that 'perhaps they had less of a patriotic feel for life aboard ship, less sense of connection with officers'. ${ }^{40}$

Elsewhere, Malcomson offers an intriguing analysis of sex on board naval warships, something he also sees as contributing to 'disorder'. He finds that inappropriate heterosexual behaviour was generally overlooked by naval authorities, with accusations of rape rarely followed up. He also argues that sexual disease was not the troublesome blight that some scholars have imaged it to be: only six of the 409 sailors invalided home were as a result of venereal disease. The most notable analysis focuses on sodomy in the navy, and on six courts martial relating to sexual behaviour that occurred on the two stations under consideration. $\mathrm{He}$ shows that charges of homosexual behaviour were incredibly hard to prove, but when sailors were found guilty they could be severely punished. Sometimes, informal solutions could be found to ensure that crews disrupted by sodomy accusations were not affected: Marine Lieutenant James Watson, for example, was given a new station on land after he was acquitted of sodomy. ${ }^{41}$ The small sample makes it hard to read too much into this, and again, it is perhaps sensible to think of this book as a useful case study that will offer up numerous opportunities for future study. Seth Le Jacq, for instance, has already published an important article on sodomy in the eighteenth-century navy, and a forthcoming monograph will place Malcomson's findings into a much broader context. ${ }^{42}$

\footnotetext{
${ }^{39}$ Malcomson, Order and Disorder, pp. 150-2

${ }^{40}$ Malcomson, Order and Disorder, p. 135

${ }^{41}$ Malcomson, Order and Disorder, p. 160

${ }^{42}$ Seth LeJacq, 'Buggery's travels: Royal Navy sodomy on ship and shore in the long eighteenth century', Journal for Maritime Research, 17.2 (July 3, 2015), pp. 103-116. See also his monograph Run Afoul: Sodomy, Masculinity, and the Sailing Royal Navy (forthcoming).
} 
The final section of the book, and perhaps the most important, considers responses to disorder. Here we again return to the relationship with shipboard behaviours and the reach of the state, as Malcomson details how the Admiralty attempted to subdue or deter 'disorder'. Primarily this was done through punishment, and in some ways his findings fit with what we already know: it is argued that that activity that disrupted the peaceful equilibrium of the 'wooden world' - such as theft, and 'perceived inappropriate sexual behaviour' - were punished most severely. ${ }^{43}$ Elsewhere, though, the author paints a more brutal picture of life at sea than many revisionist historians. He shows how the officers of the navy were employing more lashes per flogging during the War of 1812 than ever before (191), that 38.9 per cent of ships' crews witnessed 'excessive punishment' (i.e. more than fifty lashes) at some point, and that punishment depended far more on the ship's officers than on any standardised system. ${ }^{44}$ In this sense, it could be argued that Admiralty's centralised authority only went so far. Malcomson's sample certainly tells a far more brutal story of naval punishment than previous studies undertaken by Byrn and Eder and undermines N.A.M. Rodger's argument that naval discipline became less severe after $1806 .{ }^{45}$ As the author suggests, his findings fit much better with Linebaugh and Hay's perspective of the use of punishment as a means of dominating the lower orders. ${ }^{46}$ In his words, the evidence of this period demonstrates that 'judicial terror was alive and well'. 47

Malcomson has produced an important book that will prompt numerous other studies of shipboard control and disorder. Indeed, such works will be needed to test some of his wider arguments about the increased brutality of naval discipline, or the growing reach of the state. He deserves credit, too, for ensuring that naval sailors are seen by historians not as impotent vassals of governmental authority, but as active agents in their own lives. Thousands of sailors, it would appear, rebelled against the Admiralty's desire for control. Some did this aggressively, through desertion or disobedience, but others found other ways to diverge from authority, through illegitimate activities such as theft or sex. What is absent from this study, though, is a deeper consideration of the larger group of sailors who did not oppose or

\footnotetext{
${ }^{43}$ Malcomson, Order and Disorder, p. 192

${ }^{44}$ Malcomson, Order and Disorder, p. 201

${ }^{45}$ N.A.M. Rodger, The Command of the Ocean: A Naval History of Britain, 1649-1815 (London: Allen Lane, 2004), p. 493

${ }^{46}$ Malcomson cites both Linebaugh, The London Hanged: Crime and Civil Society in the Eighteenth Century (Cambridge: Cambridge University Press 1992); and Douglas Hay, 'War, Dearth and Theft in the Eighteenth Century: The Record of the English Courts', Past and Present, Vol. 95, No. 1 (May 1982), pp. 117-160

${ }^{47}$ Malcomson, Order and Disorder, p. 236
} 
undermine 'order'. This is acknowledged in the conclusion, in which Malcomson notes that 'The overall picture aboard the ships of the Royal Navy on the North American and West Indies station during the War of 1812 is one of relative order', and that 'some simply accepted their experience as it was' ${ }^{48}$ Other seamen found more lawful ways of living; they ate, slept, recreated, and generally avoided punishment. It may be that the 'new naval history' needs to look next at this larger body of men.

Malcomson's views on the increasing power of the state across the eighteenth century are supported for the most part by the fourth book here reviewed. Robert Sutcliffe's British Expeditionary Warfare and the Defeat of Napoleon, 1793-1815 is a rigorous and detailed analysis of the role of the Transport Board, the body tasked with procuring shipping upon the open market, to be used by other governmental departments. Instituted shortly after the beginning of the French Revolutionary Wars in 1794, its primary role was military, furnishing thousands of tons of shipping to see men, material, food and horses around the world. As he points out in an efficient introduction, this is the first comprehensive study of the Transport Board. As with the other books considered here, it goes beyond the navy, and ask bigger questions about the role of government in warfare, its machinery rapidly changing under the pressures of war.

The task faced by the Transport Board was indeed immense. At the height of the war over 173,000 soldiers were serving abroad, all of whom needed to be supplied, while Royal Navy fleets stationed around the world added another 140,000 sailors who needed feeding. On top of this, Britain launched more than 50 major seaborne expeditions during the Revolutionary and Napoleonic War, which raised even greater short-term shipping challenges. According to a 1799 estimate, transporting 60,000 men overseas required as many as 1,400 vessels of 200300 tons. ${ }^{49}$ For much of the war these numbers proved prohibitive - the 1799 expedition did not take place - but it is testament to Board's increasing effectiveness that in 1805 and 1809 forces of equivalent size were sent to the continent. To transport them, an immense support system was required, and extensive engagement with the mercantile community. Government competed with demands of trade by chartering ships on the open market and overall thousands of merchant ships needed to be hired as transports, often at short notice: in

\footnotetext{
${ }^{48}$ Malcomson, Order and Disorder, p. 221

${ }^{49}$ Robert Sutcliffe, British Expeditionary Warfare and the Defeat of Napoleon, 1793-1815 (Woodbridge: Boydell Press, 2016), p. 14
} 
September 1808 there were 709 transports under hire. Arranging shipping on this scale required a good communications and co-operation across a wide spectrum of government boards, ship-owners and contractor supplies. Taken together, the Transport Board offers a fascinating case study not only into the workings of the state, but also of its relationship with the broader economy.

The Board succeeded or failed on the strength of its relationship with merchant contractors. The early chapters deal thematically with the Board' activities, looking firstly at how transports were 'brought forward' for government service, before assessing how it dealt with competing demands for shipping. Procurement was usually done by competitive tender advertised at Lloyds Coffee House and in the waiting room of the Board, where ship-owners and brokers congregated. The Transport Board took steps to ensure that it obtained the best ships at the best value to the public by increasing the number of brokers that it dealt with on a regular basis. From the start, it also attempted to balance the competing demands of cost and efficiency, ensuring that the government's transport needs were met satisfactorily, but doing so at the cheapest possible price. As Sutcliffe notes, 'Economics, not patriotism, was the principal motivation for ship-owners', and ultimately the market determined the availability of shipping for government service. ${ }^{50}$ The Board proved skilled at using the market, raising the 'freight rate' to encourage more ship-owners to come forward and counteract competition from other trades, but sometimes resisting this urge in order to keep its existing contractors happy. Those contractors that failed to live up to the Board's standards were dealt with harshly: Mr Herring of 'Herring and Richardson' was struck off the list of approved brokers when he was deemed to have manipulated the system. Overall, Sutcliffe's research suggests that securing shipping took between 10 and 16 weeks, an impressive procurement speed. ${ }^{51}$

Perhaps the most interesting issue raised by Sutcliffe is whether the Transport Board helped or hindered the British mercantile marine. Given the size of the merchant marine, it would be easy to dismiss the Board's significance. At the peak of demand in 1808, for instance, the government hired 1,012 ships when there were in theory 22,646 ships available on the market. However, as Sutcliffe notes, once deductions are made for shortages of seamen, and the fact that many ships were either registered outside Britain or were simply too small for its

\footnotetext{
${ }^{50}$ Sutcliffe, British Expeditionary Warfare, p. 71

${ }^{51}$ Sutcliffe, British Expeditionary Warfare, p. 122
} 
purposes, the proportion available to the Board was significantly smaller, perhaps as low as 9 per cent. This meant that at times of peak demand the government was using well over 30 per cent of the fleet of ships over 220 tons, peaking at $39 \%$ in November $1808 .^{52}$ For much of the war - Sutcliffe argues until 1805 - the government actually sustained mercantile shipping, 'pumping millions of pounds into the industry' and offering employment to ship-owners who had seen their usual markets hit by the closure of enemy ports. There is also evidence that as the demand for shipping increased after 1805, the Board's hiring practices caused higher freight rates, commodity shortages and higher commodity prices. ${ }^{53}$ The Board's impact was much more significant than historians have previously thought.

Having dealt with the economic context, Sutcliffe then moves on to consider the strategic impact of the Board. A chapter on 'conjunct operations', or amphibious assaults as we would now call them, offers clear justification for the author's wider argument about the Board's contribution to the war effort: it was here, he argues, that the it made real and direct contribution to the defeat of Napoleon. The final third of the book provides a more chronological narrative of the Transport Board's activities throughout the period A chapter focussing on 'Castlereagh's European Expeditions, 1805-08' shows how it developed a reputation for competence, so much so that the Sick and Hurt Board was disbanded and all of its duties transferred to the Transport Board. A chapter on the difficult years of 1808-9 shows the Board managing increasing demand and a narrowing market with skill. The enquiry into the disastrous Walcheren expedition found no fault with Transport Board; indeed, shipping had been prepared in extremely quick time (10 weeks). ${ }^{54}$ A final chapter, 'The Turning of the Tide', brings the narrative through to the end of the war.

This is an important book. It leaves the reader in no doubt that the Board played a crucial role in the defeat of France, and had a major impact onthe British economy. Most importantly, it demonstrates how studying military bureaucracies - in this instance including but not limited to the navy - can tell us much about the development of the British state. Other aspects of the book are more problematic. The book's structure, with thematic chapters followed by more chronological ones, is not always the most helpful, and leads to some repetition. Additionally, there are areas where Sutcliffe's interpretations are over-stretched. For instance, he is at pains

\footnotetext{
${ }^{52}$ Sutcliffe, British Expeditionary Warfare, p. 89

${ }^{53}$ Sutcliffe, British Expeditionary Warfare, pp. 99, 243

${ }^{54}$ Sutcliffe, British Expeditionary Warfare, p. 240
} 
to point out that the Transport Board's effectiveness meant that Britain was never forced to resort to requisitioning ships. ${ }^{55}$ However, he gives no sense that such a policy was ever considered, or that it even would have occurred to an eighteenth-century mind in which the sanctity of property was prominent. His statement elsewhere that 'without doubt the previous administrative arrangements would have been totally inadequate' errs too closely to counterfactual history. ${ }^{56}$ Nonetheless, it is clear that the Board's management of shipping procurement was superior to those earlier in the eighteenth century, and there is no doubt that the strength and size of the British merchant fleet gave the country a significant military advantage in the conflicts against Revolutionary and Napoleonic France.

In the early twenty-first century, naval historical scholarship is more firmly connected to the historical mainstream than ever before. Boydell and Brewer deserve enormous credit for facilitating the publication of research that is expanding both the reach and remit of naval history. We might query the price of the books in question, which certainly limits their audience, but this is an issue facing academic publishing more broadly. What all of the books have in common is the ambition to look beyond traditional studies of Britain's naval past, and instead locate the navy within broader historiographical contexts, whether commenting on the navy's place in wider British society or analysing what the navy can tell us about the reach of the state. These approaches are not unique, and countless other scholars are navigating similar intellectual waters, using the navy to illuminate broader historical debates. There is not one 'new naval history'; instead, it takes many forms and offers a multiplicity of different agendas and perspectives. ${ }^{57}$ The books reviewed here represent four important examples of this academic development and reflect just how much the discipline is changing.

\footnotetext{
55 Sutcliffe, British Expeditionary Warfare, pp. 2, 238

${ }^{56}$ Sutcliffe, British Expeditionary Warfare, p. 242

${ }^{57}$ Quintin Colville and James Davey, eds. A New Naval History (Manchester: Manchester University Press, 2018)
} 